\title{
Health status of blood cockle's Tegillarca granosa (Arcidae: Bivalva) from three different farms along the Strait of Malacca
}

\author{
Muhammad Ilman Ismui ${ }^{1}$, Ferdaus Mohamat-Yusuff ${ }^{1,2,}{ }^{*}$, Amirul Azuan Mad Joni ${ }^{1}$, \\ Nurhanin Aqila Mohammed Noor ${ }^{1}$, Aqilah Mukhtar ${ }^{3}$, Syaizwan Zahmir Zulkifli ${ }^{1,2}$ \\ ${ }^{1}$ Department of Environment, Faculty of Forestry and Environment, Universiti Putra Malaysia, 43400 UPM Serdang, Selangor, Malaysia \\ ${ }^{2}$ International Institute of Aquaculture \& Aquatic Sciences (I-AQUAS), Universiti Putra Malaysia, Jalan Kemang 6, Batu 7, Teluk Kemang, \\ 71050 Port Dickson, Negeri Sembilan, Malaysia \\ ${ }^{3}$ Department of Biology, Faculty of Science, Universiti Putra Malaysia, 43400 UPM Serdang, Selangor, Malaysia
}

\section{ARTICLE INFO}

Article history:

Submitted 18 May 2020

$1^{\text {st }}$ Revision 30 June 2020

Accepted 31 July 2020

Published online 31 July 2020

Keywords:

Blood cockle

Tegillarca granosa

gill

biological attributes

anatomy

\section{ABSTRACT}

The annual production of Tegillarca granosa in Perak and Selangor is constantly decreasing since 1996, however a different production pattern was reported in Johor where it was fluctuated for the past years. Thus, this study was done to provide information on the health condition of T. granosa through morphological observation of the biological attributes and the anatomy of the gill's tissue. Sampling work was done in dry seasons between May and July 2019 at Bagan Pasir Laut, Perak, Kuala Sungai Buloh, Selangor and Sungai Ayam, Johor. A group of 22-30 T. granosa were collected randomly from each site for biological attribute measurement and the mean were analyzed using Kruskal-Wallis. Six to seven cockles with shell length ranging 25.00 - $35.00 \mathrm{~mm}$ were selected for the gill's histological observation. Fresh $T$. granosa samples were preserved in $10 \%$ formalin before dissection and then the gills were fixed in Bouin's solution, followed by histological standard procedures and haematoxylin and eosin staining. Results indicated a significant difference of biological attributes was detected between the sites with the lowest measurement found in samples from Bagan Pasir Laut. The highest body weight $(14.08 \mathrm{~g})$ was found in samples from Kuala Sungai Buloh, followed by Sungai Ayam (10.81g) and then Bagan Pasir Laut (8.08g). The histology of the gill filaments of samples from Sungai Ayam are full of hemocytes, wellstructured epithelium cells with cilia in comparison to samples from Bagan Pasir Laut, and Kuala Sungai Buloh. The most degenerated gill filaments were found in samples from Bagan Pasir Laut. Thus, suggesting the unhealthy condition of the gills, affects the shell sizes and body weight of $T$. granosa between the three established farms.

()2020 Indonesian Institute of Sciences (LIPI).

\section{Introduction}

The blood cockle, Tegillarca granosa farming is a major marine aquaculture activity in Southeast Asian countries such as in Malaysia because they have a fast growth rate and reproduce throughout the year. According to the annual report by the Department of Fisheries, the production trend of $T$. granosa is constantly decreasing especially at Penang, Perak, and Selangor (DOF, 2019). A different production pattern was reported in Johor where it fluctuated for the past years. Several attempts have been done to coup this issue including farm expansion and

\footnotetext{
${ }^{*}$ Corresponding Author

F. Mohamat-Yusuff: ferdius@upm.edu.my
}

introduction of new farm areas as in Johor (DOF, 2017). The farm expansion at Selangor has increased twice the size in 1995 , from 4,753 hectares to more than 10,000 hectares in 2010 or equal to more than $200 \%$ expansion (Mohd and Faizal 2013).

However, the positive result in Selangor was not sustained as the yield constantly decreasing in the following years and worsening starting from the year 2016 (DOF, 2019). This shows that area is not the main factor to increase the production yield. The factor leads to low productivity was mostly because of high mass mortality incidence and could be due to the health condition of $T$. granosa, prey-predator relationship, parasitic effect, and pollution of land and water. Intense studies on potential pollution at the farming site (Ramli et 
al., 2013), food availability (Yurimoto et al., 2014), T. granosa reproductivity (Yurimoto et al., 2014) however are focusing on the Selangor state and very limited to other states. Besides, only a few journals were addressing the health condition of T. granosa based on the gills' histology with none in Malaysia. Previous histopathological studies on T. granosa in Malaysia was focusing on the digestive organs and the stomach content of $T$. granosa and limited to the Selangor state. Since $T$. granosa has low motility which means they do not move too much, so the gills are also functioning to capture food by the filter-feeding process as well as a respiratory organ (Giribet, 2008). This shows that gills are one of the most important organs for T. granosa and tissue deformities can affect the uptake of food and oxygen which can cause fatality. Other than that, a few characteristics of a healthy T. granosa are they have a reddish inner body, bigger shell, heavier shell, and thicker shell. Limited food availability and food competition can make blood cockles appear to be smaller and have a thinner shell except for the young ones. According to Harith et al.(2016), T. granosa can grow up to $7 \mathrm{~g}$ and having a length of $35 \mathrm{~mm}$ in overpopulated area while much bigger $T$. granosa that could reach $80 \mathrm{~mm}$ was observed in less density area as in Joni et al. (2019). However, since the area was not the case in Selangor state, therefore, the biological attributes would reflect whether T. granosa in the sampling area are is in a good condition or not.

Therefore, this study will contribute information on the health condition of $T$. granosa through morphological observation of the biological attributes and the anatomy of histological condition of the gill' s tissue structure. Any alteration or deformity will be identified, and comparison will be made to see the difference in gills tissue condition of T. granosa. This study is following Sustainable Development Goals 14, life below water with the aim is to protect marine life and ecosystem from pollution while managing them sustainably so that the resources is enough for the current needs without making the resources become limited to the future generation.

\section{Materials and Methods}

\subsection{Sampling works}

Samples of Tegillarca granosa were collected from three established farm in Perak, Selangor, and Johor. Details of the locations are as in Table 1 and Figure 1. The sampling works was done in dry seasons in the end of May 2019 at Perak and Selangor and in early July at Johor to avoid the cockle' s spawning season. Samples of T. granosa were collected with a hand dredge net of $1.5 \mathrm{~cm}$ mesh. A group of 22-30 T. granosa were collected randomly from each site for biological attribute measurement and transported alive to the laboratory.

\subsection{Biological attributes measurement}

The biological attributes selected in this study were based on the shell length, total body weight, and shell thickness among the group of 22-30 T. granosa samples. Total body weight was measured using an analytical balance $( \pm 0.01 \mathrm{~g})$ and the average of the weight was calculated using equation (1):

$$
\text { Average Shell Weight }=\frac{\text { Total Shells Weight }}{\text { Total number of sample }}
$$

The length of the shell and the thickness of the shell were measured using a pair of Vernier calipers $( \pm 0.05 \mathrm{~mm})$.

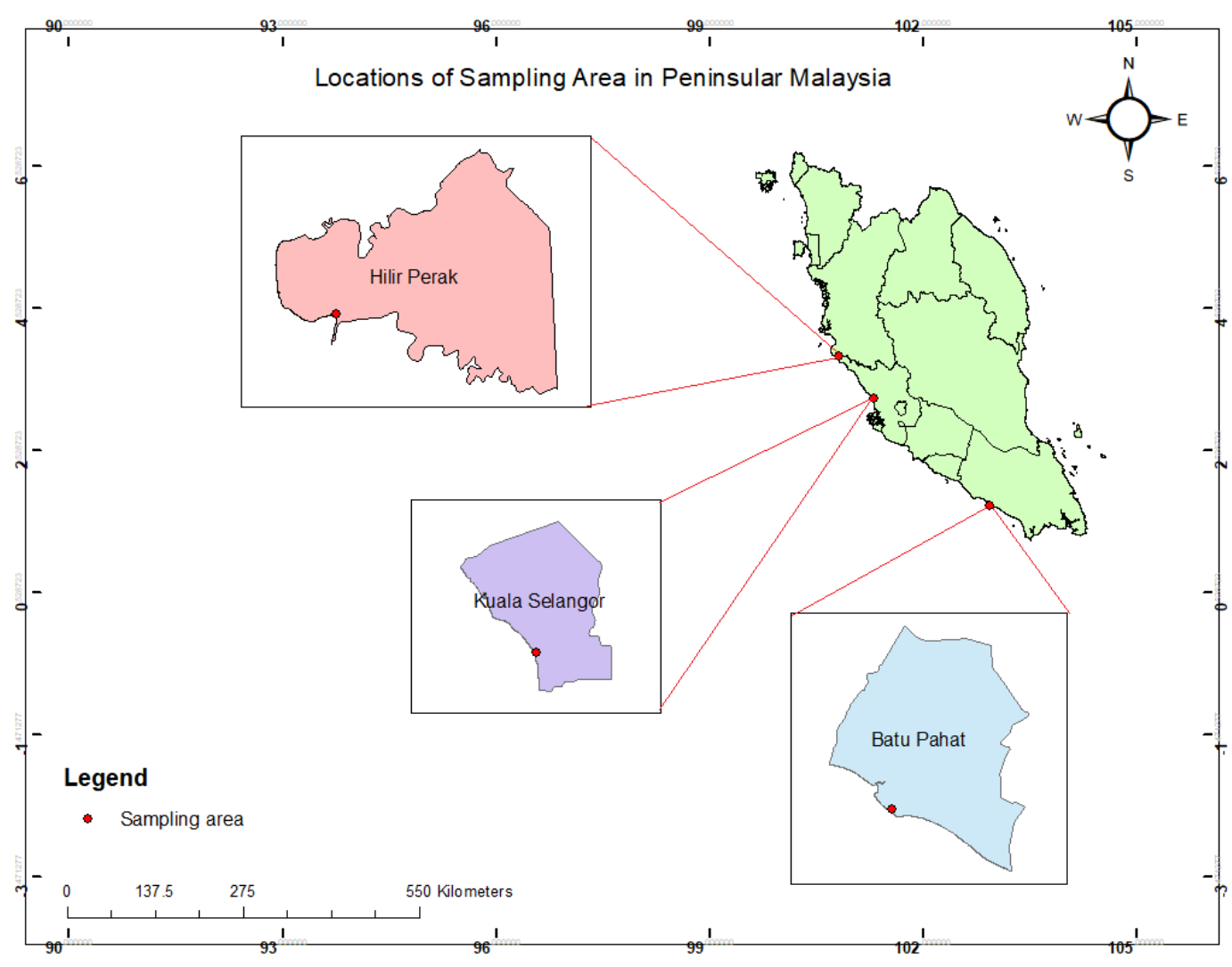

Figure 1. Map of sampling sites and their location along the west coast of Peninsular Malaysia 
Table 1. Details of the sampling locations including the coordinate, district, and further description

\begin{tabular}{|c|c|c|}
\hline Site & Coordinate & District, State, and Description \\
\hline Bagan Pasir Laut & $\begin{array}{l}3^{\circ} 51 ' 20.556 " \mathrm{~N} \\
100^{\circ} 49 ' 26.1444 " \mathrm{E}\end{array}$ & $\begin{array}{l}\text { Hilir Perak, Perak } \\
\text { Situated in the estuary, receiving periodically fluctuating salinities during } \\
\text { the inter monsoon period. }\end{array}$ \\
\hline Kuala Sungai Buloh & $\begin{array}{l}3^{\circ} 15^{\prime} 22.4136 " \mathrm{~N} \\
101^{\circ} 18^{\prime} 5.245^{\prime \prime} \mathrm{E}\end{array}$ & $\begin{array}{l}\text { Kuala Selangor, Selangor } \\
\text { Situated away from the estuary and receiving full strength seawater. }\end{array}$ \\
\hline Sungai Ayam & $\begin{array}{l}1^{\circ} 45^{\prime} 11.2968^{\prime \prime} \mathrm{N} \\
102^{\circ} 55^{\prime} 47.863^{\prime \prime} \mathrm{E}\end{array}$ & $\begin{array}{l}\text { Batu Pahat, Johor } \\
\text { Situated away from the estuary and receiving full strength seawater. }\end{array}$ \\
\hline
\end{tabular}

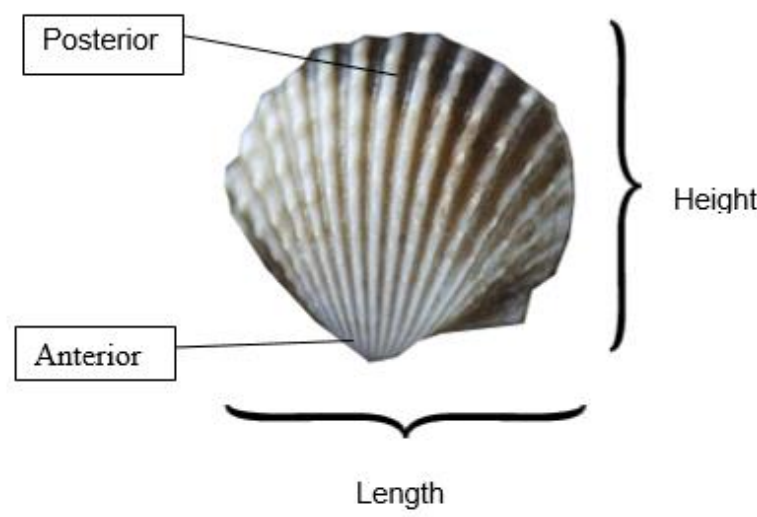

(a)

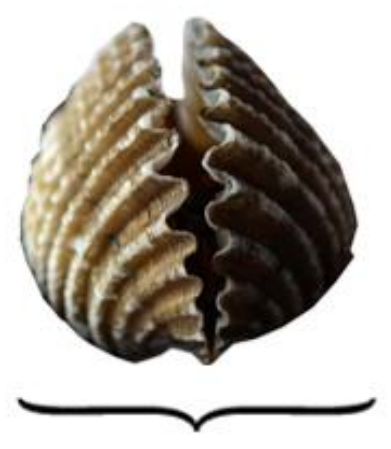

Thickness

(b)

Figure 2. (a) External appearance of $T$. granosa indicating the shell length and height; (b) External appearance of $T$. granosa indicating the shell thickness

The length of the cockle was determined by measuring the length along the anterior-posterior axis as shown in Figure 2(a). The average of the shell length was calculated using equation (2):

$$
\text { Average Shell Length }=\frac{\text { Total Shells Length }}{\text { Total number of sample }}
$$

The shell width or shell thickness is the furthest distance on the outside of closed valves as shown in Figure 2(b). The average shell thickness was calculated by using equation (3):

Average Shell Thickness $=\frac{\text { Total Shells Thickness }}{\text { Total number of sample }}$

\subsection{Histological analysis}

Six to seven $T$. granosa with shell length ranging 2.50 $-3.50 \mathrm{~cm}$ were selected from each site and immersed in a $10 \%$ formalin seawater solution in a $500 \mathrm{ml}$ beaker to fix them before dissection. After a day, the gills were removed from the main body and placed inside universal bottles filled with Bouin's solution. The gills samples were processed for optical microscopy where it was conducted according to the standard histological procedures. First, the gills were dehydrated with increasing ethanol series (50\%, 70\%, 95\%). The samples were then impregnated in paraffin wax of melting point $55-60{ }^{\circ} \mathrm{C}$ to make paraffin block. Tissues of the gills were cut with $5-10 \mu \mathrm{m}$ thick by using a microtome (Slaoui \& Fiette, 2011). The tissues were then stained with Ehrich's hematoxylin and then counterstained with Eosin (Kandeel et al., 2013), cover the tissue with a coverslip and observed under a light microscope.

\subsection{Statistical analysis}

The mean of the biological attributes' measurements was analyzed using Kruskal-Wallis to identify the mean variation between sampling sites. The relationship between the biological attribute measurements was performed via Spearman's correlation.

\section{Results}

\subsection{Biological attributes}

The average measurement for all biological attributes showed in Figure 3, and the variation between sampling sites was shown as Pairwise comparison in Figure 4. The average shell thickness of T. granosa was recorded in the range $18.20-22.40 \mathrm{~mm}$; the average shell length was between $26.80-33.20 \mathrm{~mm}$, and the average body weight was between 8.18 - $14.08 \mathrm{~g}$ (Figure 3). The Kruskal-Wallis test provided very strong differences with $p<0.001$ of shell thickness between Bagan Pasir Laut and the other two sites as indicated with Yellow lines, no significant differences between samples from Sungai Ayam and Kuala Sungai Buloh as the $p=1$, and no line was drawn in the Pairwise test between Sungai Ayam and Kuala Sungai Buloh shown in Figure 4(a). In Figure 4(b), the average shell length between samples from Bagan Pasir Laut and the other two sites were significantly different with $p<$ 0.001 and indicated with Yellow lines. Black line was drawn between Kuala Sungai Buloh and Sungai Ayam as the $p$ value was $0.05<p<1.00$. Meanwhile, the average body weight between all three sites was significantly different with the $p<0.05$ as shown by the Yellow lines in 


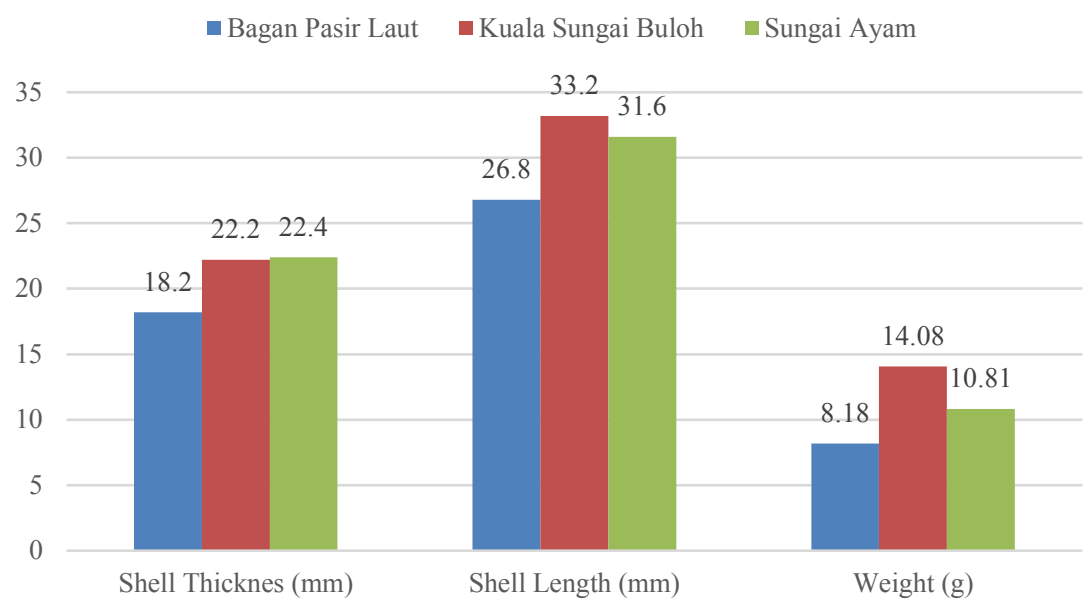

Figure 3. Average biological attributes (shell thickness, shell length, and body weight) of $T$. granosa between three sampling sites; Bagan Pasir Laut, Kuala Sungai Buloh and Sungai Ayam

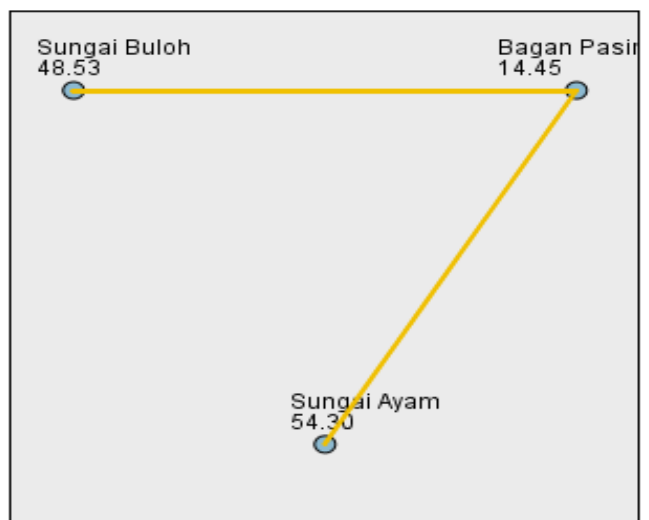

(a)

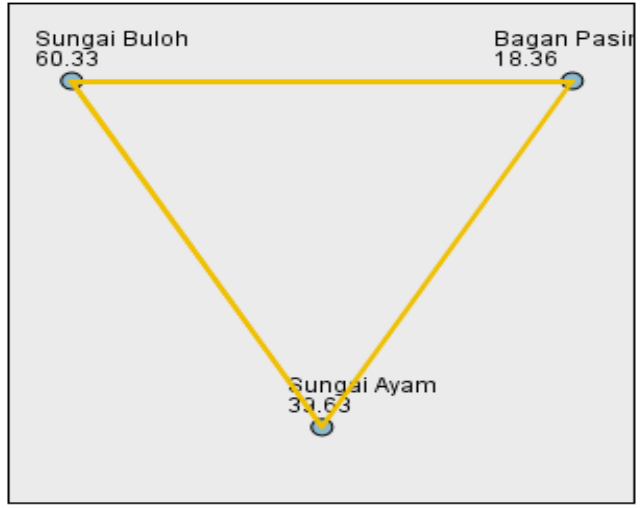

(c)

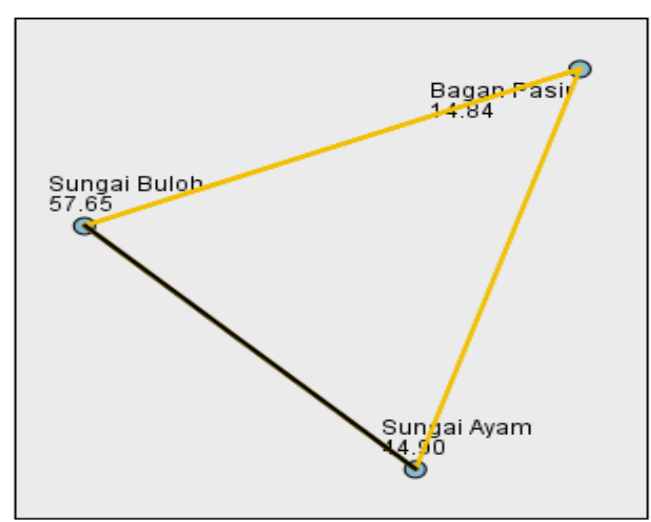

(b)

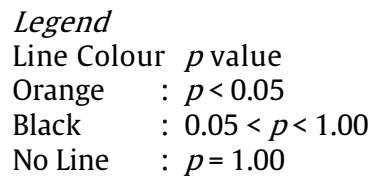

Line Colour $p$ value

Orange : $p<0.05$

No Line $\quad: p=1.00$

Figure 4. Pairwise comparison of T. granosa biological attributes between sampling sites; (a) comparison between average shell thicknes; (b) comparison between average of shell length; and (c) comparison of body weight

Figure 4(c). Results on the biological attributes suggesting that $T$. granosa collected from Bagan Pasir Laut were the smallest in size with average shell thicknes was $18.20 \mathrm{~mm}$ and shell length was $26.80 \mathrm{~mm}$, while samples from Sungai Ayam and Kuala Sungai Buloh were having almost identical size with length 31.60 and $33.20 \mathrm{~mm}$, and shell thickness 22.20 and $22.40 \mathrm{~mm}$ as in Figure 3. However, the shell sizes alone are not in line with the body mass as the heaviest $T$. granosa samples were recorded in samples from Kuala Sungai Buloh (14.08 g) while samples from Sungai Ayam was significantly having lower weight
(10.81 g) despite samples from these two sites were having identical shell length and shell thickness.

Correlation matrix using Spearman's correlation was performed to investigate the relationship between the biological attribute within the sampling site as shown in Figure 5. Results indicated a strong positive correlation identified between the shell length, shell thickness and body weight of $T$. granosa in Bagan Pasir Laut, between shell length and body weight in sample from Kuala Sungai Buloh and between shell thickness and body weight of sample from Sungai Ayam at $p<0.05$ (Figure 5). Low 

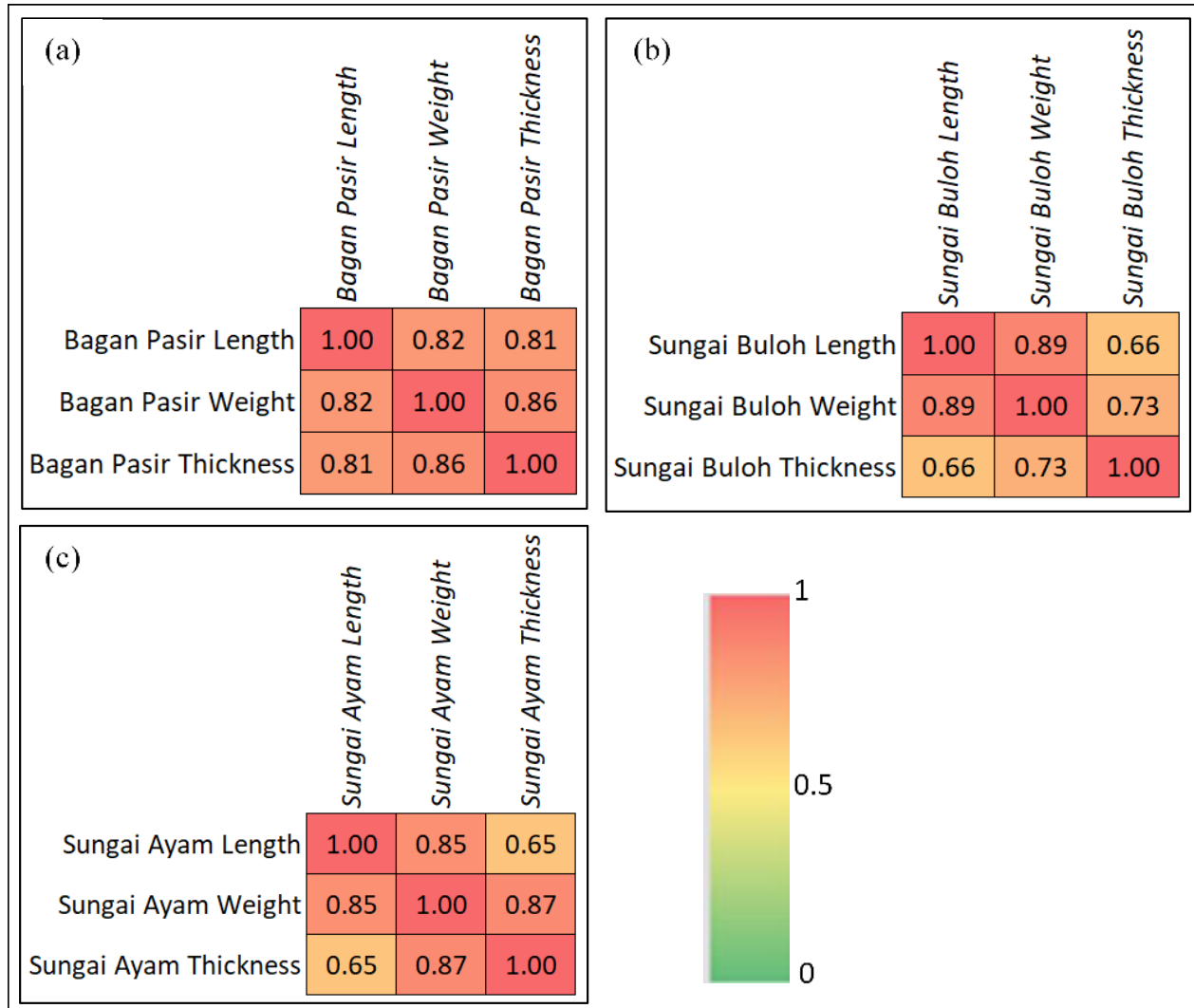

Figure 5. The correlation matrix that show the relationship of the T. granosa biological attributes within a site; (a) Bagan Pasir Laut with the lowest is 0.81, (b) Kuala Sungai Buloh with the lowest is 0.66 and (c) Sungai Ayam with the lowest is 0.65.

correlation values were found between the shell thickness and the shell length as well with the body weight of samples from Kuala Sungai Buloh and between shell length and shell thickness of the sample from Sungai Ayam (Figure 5.c).

\subsection{Histological analysis}

The gill's tissue structure of $T$. granosa from each sampling site are shown in Figure 6. Histology of the gills was divided into two sections, the intermediate zone (IZ) and the frontal zone (FZ). The gill filaments in samples collected from Bagan Pasir Laut found to have severe deformities such as the filaments in the intermediate zone were thin, crimpled structure with degenerated and shrunken epithelium layers, while the frontal zone experienced the same epithelium deformities along with cilia degeneration, presence of gills swelling and consisted of large vacuoles (Figure 6(a) and Figure 6(b)). The gill filament of the sample from Kuala Sungai Buloh appeared with fewer deformities such as the intermediate and frontal zones were thin, but contains a tall columnar structure of epithelium tissues especially at the frontal zones, no presence of vacuole as compared to the samples from Bagan Pasir Laut, however a noticeable disappearance of frontal and lateral cilia (Figure 6(c) and Figure $6(d)$ ). The histological observation of the gill filaments of samples from Sungai Ayam shows the filaments in the intermediate zones are thick, almost each has thick epithelium completed with lateral cilia, while the frontal zone consisted of the epithelium with frontal cilia as shown in Figure 6(e) and Figure 6(f). Besides, the filaments in sample from Sungai Ayam were full of hemocytes (Figure 6(e) and Figure 6(f)).

\section{Discussions}

Results on the biological attributes of $T$. granosa or previously known as Anadara granosa collected in this study corroborated with findings in previous works as shown in Table 2. The average shell length of T. granasa in Bagan Pasir Laut, Perak were within the range reported in the study by Mirzaei et al. (2015) and Oon (1980), however, the value was much lower in comparison to samples from Kuala Sungai Buloh, Selangor, Sungai Ayam, Johor and findings of other remaining studies in Table 2. In the case of the sample from Kuala Sungai Buloh Selangor, the average shell length in the present study was in the range with the sample collected from the same site in the year 2010 as in Yurimoto et al. (2014b) but the value was higher than the sample collected in the year 2012 as in Yurimoto et al. (2014a). Likewise, the average shell length of samples from Sungai Ayam Johor was within the range with the sample from Kuala Sungai Buloh collected on the present study and in the works by Yuri moto et al. (2014b), Mirzaei et al. (2015), Pathansali (1996), and Broom (1985), and slightly higher than the sample in the work by Yurimoto et al. (2014a) and Oon (1980). The shell length of $T$. granosa recorded in Malaysian samples was lower as compared to samples from Kikinda Bay India (Narasimham 1988a,b) and from Blue Mud Bay, Australia (Faulkner, 2009) as shown in Table 2. The shell thickness in the present study is not comparable with previous work due to limited information on this parameter. The average body weight of samples in the present study within the range of samples in Merzaei et al. (2015) as shown in Table 3. The lowest weight recorded in this study was in the sample from Bagan Pasir Laut, Perak. Findings of the 

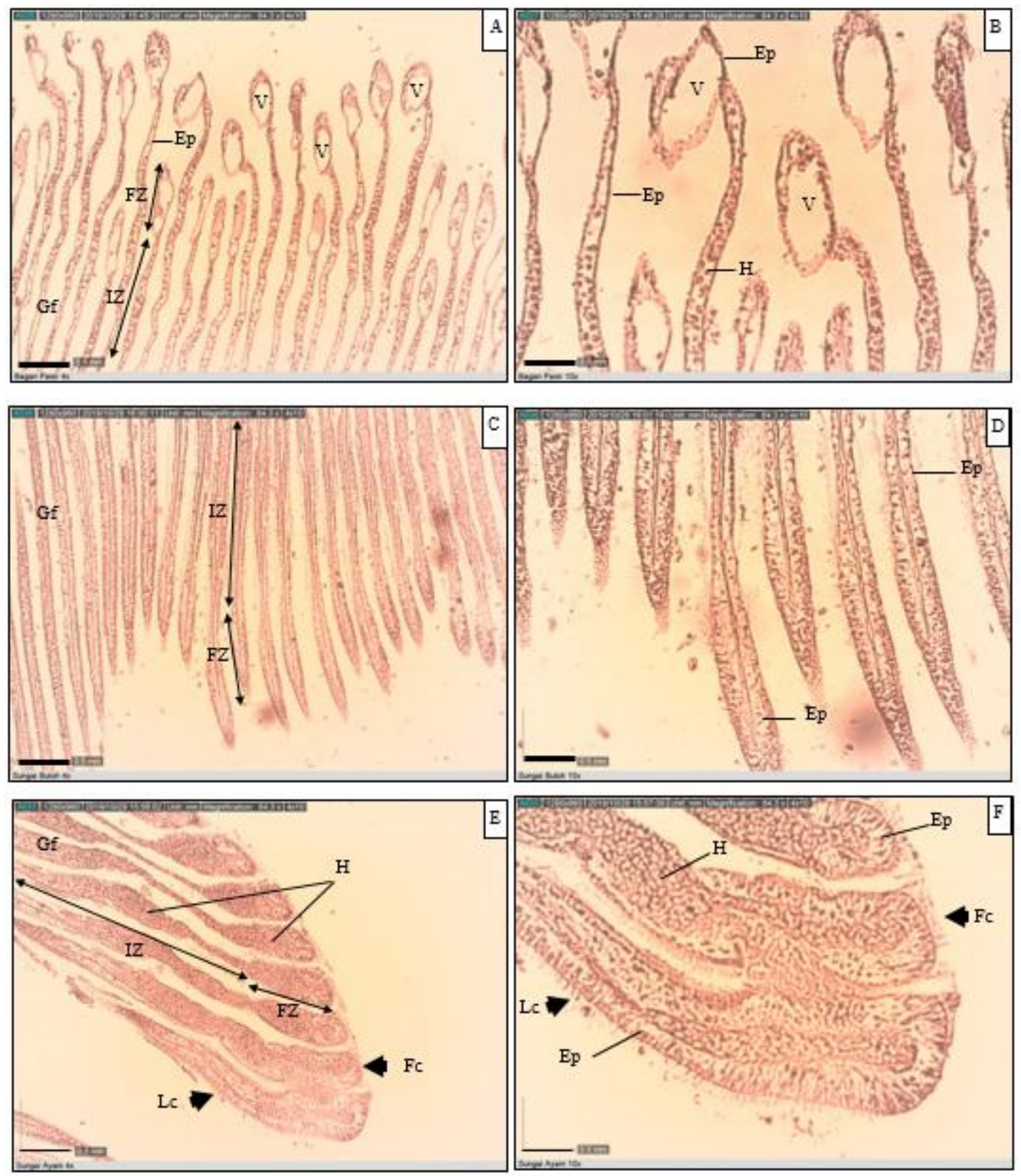

Figure 6. Histological observation of gill filament; (a) and (b): Bagan Pasir Laut 4x and 10x power magnification; (c) and (d) Kuala Sungai Buloh 4x and 10x power magnification: (e) and (f) Sungai Ayam 4x and 10x power magnification. Scale bar $=500 \mu \mathrm{m}$. Where Ep: Epithelium, Fc: Frontal cilia, FZ: Frontal Zones, Gf : Gill filament, H: Haemocyte, IZ: Intermediate Zones, Lc: Lateral cilia and V: Vacuole

biological attributes indicated sample from Bagan Pasir Laut was the smallest in comparison to the other study sites and large shell sizes were not indicating the high body mass of $T$. granosa as the case of samples from Kuala Sungai Buloh with average body weight $14.08 \mathrm{~g}$ while samples from Sungai Ayam was significantly having lower weight $10.81 \mathrm{~g}$ despite they were having almost identical shell length and shell thickness.

Findings also suggested samples from Bagan Pasir Laut seem to have isometric growth as they have a strong positive correlation within each biological attribute, while a sample from Kuala Sungai Buloh and Sungai Ayam were experienced allometry growth since one or two parameters was or were not proportionally correlated (Figure 5). The potential factors for the variation of biological attributes among sampling sites are expected because of the site locality and influence of biological and ecological factors such as water temperature, density, and shore level at the study area as suggested by Hickman (1979) and later by Mirzaei et al. (2015), and food availability between the same species in different sites as suggest by Frechette et al., (1992) and Nakaoka (1992). The location of the sampling site at Bagan Pasir Laut, Perak was in the river estuary that received episodic changes in river flow and experienced fluctuated water salinity thus influence food availability. The structure of phytoplankton populations in the estuary was much reduced in the number of species that are adapted to survive in a highly changeable estuarine environment (O'Boyle \& Silke, 2010). Meanwhile, in coastal water that has stable and strong intact of the high salinity of the water column accounts for most of the natural variation in both phytoplankton species composition and biomass (O'Boyle \& Silke, 2010). Thus, this might be the reason higher measurement of 
Table 2. Compilation of Tegillarca granosa shell length by other authors in different study areas

\begin{tabular}{lll}
\hline Location & Average Shell Length $(\mathrm{mm})$ & Reference \\
\hline Balik Pulau, Penang, Malaysia & $23.5-31.5$ & Mirzaei et al., 2015 \\
*Penang Island, Malaysia & $27.5-37.5$ & Pathansali $(1996)$ \\
${ }^{*}$ Penang Island, Malaysia & $30-41.23$ & Broom (1985) \\
${ }^{*}$ Kuala Juru, Penang, Malaysia & $21-31$ & Oon (1980) \\
${ }^{*}$ Kuala Sepetang, Perak Malaysia & $25.5-30.5$ & OOn (1980) \\
Bagan Pasir Laut Perak, Malaysia & 26.80 & This study \\
Kuala Sungai Buloh, Selangor, Malaysia & $28-30 \mathrm{~mm}$ & Yurimoto et al., 2014a \\
Kuala Sungai Buloh, Selangor, Malaysia & $29.1 \pm 3.5 \mathrm{~mm}$ & Yurimoto et al., 2014b \\
Kuala Sungai Buloh, Selangor, Malaysia & 33.20 & This study \\
Sungai Ayam, Johor, Malaysia & 31.60 & This study \\
*Kakinada Bay, India & $31.5-49.5$ & Narasimham (1988a, b) \\
*Blue Mud Bay, Australia & $38.46-41.23$ & Faulkner (2009) \\
\hline *etrieved from Mirzaei et al. 2015 & &
\end{tabular}

Table 3. Compilation of Tegillarca granosa body weight by other authors in different study areas

\begin{tabular}{lll}
\hline Location & Range body weight $(\mathrm{g})$ & Reference \\
\hline Balik Pulau, Penang, Malaysia & $3.04-15.55$ & Mirzaei et al., 2015 \\
Bagan Pasir Laut Perak, Malaysia & 8.18 & This study \\
Kuala Sungai Buloh, Selangor, Malaysia & 14.08 & This study \\
Sungai Ayam, Johor, Malaysia & 10.81 & This study \\
\hline
\end{tabular}

biological attributes in the sample from Kuala Sungai Buloh and Sungai Ayam as both are situated away from the estuary and receiving full strength of seawater. The variation of body weight between samples from Kuala Sungai Buloh and Sungai Ayam is expected due to phenotypic variation that could affect the weight of soft tissue relative to shell length between locations as in Trussell (2000) retrieved from Mirzaei et al. (2015).

Results on the histological analysis of the gills organ indicated that sample from Sungai Ayam, Johor as the healthiest followed with the sample from Kuala Sungai Buloh, Selangor, and the unhealthiest samples was from Bagan Pasir Laut, Perak. Since T. granosa was collected not within the spawning seasons, thus the gills condition expected was badly affected by the environmental condition during the filter-feeding process as well as during the respiration process (Giribet, 2008). In addition, the gills condition is similar to the study of cockle exposed with copper $(\mathrm{Cu})$ by Shin et al., (2015). Thus, strengthening the potential reason of gills deformities in sample from Bagan Pasir Laut was due to exposure with polluted environment. Presence of high tissue deformities in the gills of T. granosa samples from Bagan Pasir Laut, Perak could explain the reason for low biological attributes recorded of the sample group. The unhealthy gills can affect the uptake of food and oxygen which can affect tissue growth, storage, and utilization (Frechette et al.,1992; Nakaoka,1992).

\section{Conclusion}

In conclusion, sample from Bagan Pasir Laut, Perak was found as the unhealthiest with degenerated gill filament, low hemocytes, lowest body weight and smallest in shell sizes. While sample from Kuala Sungai Buloh found to have thin gill filament with lack of frontal and lateral cilia, the heaviest body weight, and the shell length and thickness are almost equal with samples from Sungai Ayam. Thus, suggesting the unhealthy condition of the gills is expected affecting the shell sizes and weight, and may cause high mortality percentages.

\section{Acknowledgement}

This study was performed by the support of the Fundamental Research Grant Scheme 2017 (FRGS 2017) granted by the Malaysian Ministry of Higher Education. The authors would like to thank laboratory assistants at Universiti Putra Malaysia for their sincere guidance and help with sampling. Not forgetting the cooperation received from the Department of Fisheries Malaysia and representatives of cockles' farmers who cooperate in carrying out this project.

\section{References}

DOF (2017) Department of Fisheries Malaysia. Selangor - Shellfish Farming https://www.dof.gov.my/index.php/pages/view/1763

DOF (2019) Department of Fisheries Malaysia. Annual Fisheries Statistics. https://www.dof.gov.my/index.php/pages/view/82.

Frechette M., Aitken A.E. and Page L.(1992) Interdependence of food and space limitation of a benthic suspension feeder: consequences for self-thinning relationships. Marine Ecology Progress Series. Oldendorf 83, 55-62.

Giribet, G. (2008). Bivalvia. Phylogeny and Evolution of the Mollusca, 105-141.

Harith, H., Husain, M. L., \& Akhir, M. F. M. (2016). Coastal oceanographic processes associated with blood cockle (Anadara granosa) induce spawning season in Kapar, Selangor, Malaysia. Journal of Ocean Engineering and Science, 1(4), 289-299.

Hickman R.(1979) Allometry and growth of the green-lipped mussel Perna canaliculus in New Zealand. Marine Biology 51, 311-327. 
Joni, A. A. M., Yusuff, F. M., Mohamed, K. N., Kusin, F. M., \& Zulkifli, S. Z. Growth Performance of Blood Cockle (Tegillarca granosa) within Kongkong Laut Estuaries, Masai, Johor.

Kandeel, K. E., Mohammed, S. Z., Mostafa, A. M., \& Abd-Alla, M. E. (2013). Reproductive biology of the cockle Cerastoderma glaucum (Bivalvia: Cardiidae) from Lake Qarun, Egypt. The Egyptian journal of aquatic research, 39(4), 249-260.

Mohd, F., \& Faizal, R. (2013). Feeding cockles with detritus balls. Journal of Biology, Agriculture and Healthcare, 3(12), 102-107.

Mirzaei, M. R., Yasin, Z., \& Hwai, A. T. S. (2015). Length-weight relationship, growth and mortality of Anadara granosa in Penang Island, Malaysia: an approach using length-frequency data sets. Journal of the Marine Biological Association of the United Kingdom, 95(2), 381-390.

Nakaoka M.(1992) Spatial and seasonal variation in growth rate and sec-ondary production of Yoldia notabilisin Otsuchi Bay, Japan, with ref-erence to the influence of food supply from the water column.MarineEcology Progress Series88, 215-223.

Narasimham K.(1988a) Biology of the blood clam Anadara granosa (Linnaeus) in Kakinada Bay. Journal of the Marine BiologicalAssociation of India30, 137-150.

Narasimham K.(1988b) Taxonomy of the blood clams Anadara (Tegillarca) granosa (Linnaeus, 1758) and A.(T.) rhombea (Born,1780).Journal of the Marine Biological Association of India30,200-205.

Oon, N. F. (1980). Growth and mortality of the Malaysian cockle (Anadara granosa L.) under commercial culture: analysis through length-frequency data.

Pathansali, D. (1966). Notes on the biology of the cockle, Anadara granosa L. Proceedings of the Indo-Pacific Fisheries Council, 11(2), 84-98.P

Ramli, M. F. S., Hasan, F. R. A., \& Saadon, M. N. (2013). Declining production of cockles in relation to ammonia concentrations in Sungai Buloh River, Selangor. Journal of Environment and Earth Science, 3(10), 1-5.

Shin, Y. K., Park, J. J., Ju, S. M., \& Lee, J. S. (2015). Copper toxicity on survival, respiration and organ structure of Tegillarca granosa (Bivalvia: Arcidae). The Korean Journal of Malacology, 31(2), 151-158.

Slaoui, M., \& Fiette, L. (2011). Histopathology procedures: from tissue sampling to histopathological evaluation. In Drug safety evaluation (pp. 69-82). Humana Press.

Trussell G.C.(2000) Phenotypic clines, plasticity, and morphological trade-offs in an intertidal snail. Evolution 54, 151-166.

Yurimoto, T., Kassim, F. M., Fuseya, R., \& Man, A. (2014a). Mass mortality event of the blood cockle, Anadara granosa, in aquaculture ground along Selangor coast, Peninsular Malaysia. International Aquatic Research, 6(4), 177-186.

\section{Declarations}

\section{Funding statement}

This research did not receive any specific grant from funding agencies in the public, commercial, or not-for-profit sectors.

\section{Conflict of interest}

The authors declare no conflict of interest.

\section{Additional information}

Reprints and permission information is available at https://mri.lipi.go.id

Publisher's Note: Indonesian Institute of Sciences remains neutral with regard to jurisdictional claims in published maps and institutional affiliations. 